\title{
"Integration of Ukraine into the European banking system: cleaning, rebooting and Basel III"
}

\begin{tabular}{|c|c|}
\hline \multirow{5}{*}{ AUTHORS } & Andriy Ramskyi (D https://orcid.org/0000-0001-7368-697X \\
\hline & Valeria Loiko (D https://orcid.org/0000-0003-3248-1585 \\
\hline & Olena Sobolieva-Tereshchenko (D https://orcid.org/0000-0002-1086-1192 \\
\hline & Daria Loiko (D) https://orcid.org/0000-0002-2443-2719 \\
\hline & Valeriia Zharnikova (D https://orcid.org/0000-0002-4335-5149 \\
\hline ARTICLE INFO & $\begin{array}{l}\text { Andriy Ramskyi, Valeria Loiko, Olena Sobolieva-Tereshchenko, Daria Loiko and } \\
\text { Valeriia Zharnikova (2017). Integration of Ukraine into the European banking } \\
\text { system: cleaning, rebooting and Basel III. Banks and Bank Systems, 12(4), 163- } \\
\text { 174. doi:10.21511/bbs.12(4-1).2017.05 }\end{array}$ \\
\hline DOI & http://dx.doi.org/10.21511/bbs.12(4-1).2017.05 \\
\hline RELEASED ON & Tuesday, 19 December 2017 \\
\hline RECEIVED ON & Monday, 27 November 2017 \\
\hline \multirow[t]{2}{*}{ ACCEPTED ON } & Monday, 18 December 2017 \\
\hline & \begin{tabular}{|l|l|l|l|l|l|l|} 
EY \\
\end{tabular} \\
\hline LICENSE & $\begin{array}{l}\text { This work is licensed under a Creative Commons Attribution } 4.0 \text { International } \\
\text { License }\end{array}$ \\
\hline JOURNAL & "Banks and Bank Systems" \\
\hline ISSN PRINT & $1816-7403$ \\
\hline ISSN ONLINE & $1991-7074$ \\
\hline PUBLISHER & LLC "Consulting Publishing Company "Business Perspectives" \\
\hline FOUNDER & LLC “Consulting Publishing Company "Business Perspectives" \\
\hline
\end{tabular}

NUMBER OF REFERENCES

26

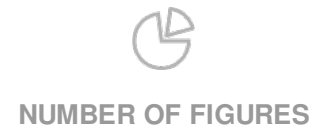

5

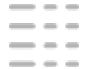

NUMBER OF TABLES

3

C The author(s) 2023. This publication is an open access article. 


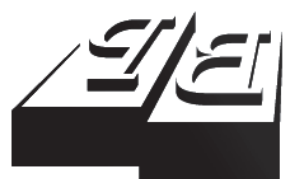

BUSINESS PERSPECTIVES

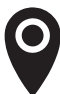

LLC "CPC "Business Perspectives" Hryhorii Skovoroda lane, 10, Sumy, 40022, Ukraine

www.businessperspectives.org

Received on: $27^{\text {th }}$ of November, 2017 Accepted on: $18^{\text {th }}$ of December, 2017

(C) Andriy Ramskyi, Valeria Loiko, Olena Sobolieva-Tereshchenko, Daria Loiko, Valeriia Zharnikova, 2017

Andriy Ramskyi, Doctor

of Economics, Professor, Head

of the Department of Finance

and Economics, Boris Grinchenko

University, Ukraine.

Valeria Loiko, Doctor

of Economics, Professor, Professor of the Department of Finance and Economics, Borys Grinchenko University, Ukraine.

Olena Sobolieva-Tereshchenko, Ph.D. (Economics), Senior Lecturer of the Department of Finance and Economics, Borys Grinchenko University, Ukraine.

Daria Loiko, Ph.D. (Economics), Associate Professor, Senior Lecture of the Department of National Economics and Finance, University of Economics and Law "KROK", Ukraine.

Valeriia Zharnikova, Ph.D. Student, Assistant Lecturer of the Department of Accounting and Taxation, Kyiv National University of Trade and Economics, Ukraine.

\section{(ㄷ) (i)}

This is an Open Access article, distributed under the terms of the Creative Commons Attribution 4.0 International license, which permits unrestricted re-use, distribution, and reproduction in any medium, provided the original work is properly cited.
Andriy Ramskyi (Ukraine), Valeria Loiko (Ukraine), Olena Sobolieva-

Tereshchenko (Ukraine), Daria Loiko (Ukraine), Valeriia Zharnikova (Ukraine)

\begin{abstract}
The urgency of the issue is related to changes in the Ukrainian banks' business environment, taking into account the impact of domestic and global financial instability and the implementation of the regulatory framework for banking regulation of the National Bank of Ukraine in accordance with the Basel Committee on Banking Supervision recommendations. The main goal of this research is to analyze the degree of implementation and compliance with the Basel III regulations in Ukrainian banking system. To carry out the research, regulatory and legislative documents of the National Bank of Ukraine, the Basel Accords, statistic data of the Ukrainian banks and the National Bank of Ukraine were used. For this purpose, the analysis of main indicators of Ukrainian banks' financial stability within the period of 2014-2017 is made. Thus, post-crisis regulatory changes have aimed at restoring bank stability. The results seem to suggest that bank regulatory changes may be repressive, for instance, cleaning and optimization of the banking system as an effective tool for anticrisis management. As a result, it was concluded that banks with foreign capital are the most stable in the banking system of Ukraine in comparison with domestic banks.
\end{abstract}

\section{Keywords}

Basel, banking system, banks, banking regulation, crisis, risk management, banks' activities, bank efficiency, National Bank of Ukraine

\section{JEL Classification E58, G21, G28, G32}

\section{INTRODUCTION}

Integration of Ukraine into the European banking sphere involves the introduction of common standards in the field of banking regulation. In the European Union, the recommendations of the Basel Committee on Banking Supervision, known as "Basel II" and "Basel III", apply for the mutual integration of the banking systems of the EU member states and beyond.

Thus, under current conditions, the need to adapt Ukrainian banking legislation to the regulatory requirements of the European Union, on the one hand, and the elimination of the consequences of crisis phenomena that spread in the Ukrainian banking sector in 2008-2009 and 2013-2015, on the other, encourage the National Bank of Ukraine (NBU) to revise the approaches to risk management in the banking system towards the introduction of Basel III standards, the final transition to which is scheduled in the EU for 2019 (Basel Committee on Banking Supervision, 2017).

The increase in the proportion of non-performing loans against the background of catastrophic depreciation of the hryvnia make banks cut their staff, save on operating costs and commissions, 
revise revenue structures, optimize deposit and loan portfolios and postpone their ambitious innovation development projects till "better" times.

In this situation, it is relevant to study the dynamics of certain indicators of banking activity and current trends in the banking sector of Ukraine in accordance with the implementation stages of Basel III recommendations.

The study provides for the use of primary information from the official sources of the NBU and data from the Basel Committee on Banking Supervision for assessing compliance with regulatory requirements as well as the results of research and analytical reviews of the banking system conducted by rating agencies of Ukraine.

As the hypothesis of the study, the assumption is made that in order to stabilize the financial state of the banking system of Ukraine, the task of clearing the banking system from the ballast of "non-transparent", "already dead" and "weak" banks becomes the top priority. This measure does not contribute to the development of confidence in the banking system and impedes the process of introducing innovative products and technologies into the domestic banking market. But, nevertheless, it allows stabilizing the financial position through high-quality risk management in the banking sector which, in turn, should strengthen the stability of the country's financial system as a whole.

\section{LITERATURE REVIEW}

The issues of managing the financial stability of the banking system, particularly related to regulatory framework placed by the Basel Committee on Banking Supervision have been the subject of research by many foreign and domestic scientists.

Scientific contributions by scientists such as Weigand, Angelini, Clerc, Cúrdia, Gambacorta, Gerali, Locarno, Motto, Roeger, Van den Heuvel and Vlček are very important for the introduction of the Basel Committee on Banking Supervision recommendations, Basel II and Basel III, into the banking systems of individual countries.

Weigand researched efficiency, growth, combination of assets, risk, operational efficiency, profitability and capital reserves of the 20 largest banks in Japan, the United States and Europe for 20032015 and made a conclusion that all banks hold more capital of the first level, than it is provided by the Basel III agreement, which led to a deep decrease in their net profit and return on equity. According to Weigand (2016, p. 75), "U.S. banks continue to exhibit a more robust post-crisis recovery, while Japanese and European banks continue to experience crisis-level conditions".

Angelini et al. (2015, p. 217) studied long-term impact of Basel III Capital and Liquidity require- ments and proved that economic costs of the new regulatory standards for bank capital and liquidity are considerably below existing estimates of the benefits that the reform should have by reducing the probability of banking crises. According to these authors, "The reform dampens output volatility modestly, although there is some heterogeneity across models. The adoption of countercyclical capital buffers can substantially amplify the dampening effect on output volatility".

Adesina and Mwamba determined possible impact of the Basel III higher tier 1 capital requirements on bank lending rates in four African countries: Kenya, Egypt, Nigeria and South Africa. According to the authors (Adesina \& Mwamba, 2015, p. 61), "the implementation of the Basel III higher equity capital requirements is likely to have smaller effect on lending rates in South Africa and Nigeria, compared to Egypt and Kenya".

The studies by Kinyariro et al. (2016) are representative of this approach: that capital requirements, leverage requirements and liquidity requirements have a positive relationship with financial distress status of commercial banks in Kenya. The adoption of Basel III influences the financial distress status of commercial banks in Kenya (Kinyariro et al., 2016).

Also important for the introduction of the Basel Committee on Basel III recommendations into the 
banking systems of individual countries are the scientific contributions of scientists from Qatar, Greece, UAE, South Africa, UK, Egypt, Russia, Kazakhstan, which reseached best practices and financial instruments that are responsible for suporting the financial stability in crises.

Anouze researched the performance of commercial banks in Gulf Cooperation Council (GCC) counG tries especially before, during, and after financial or political crises and made a conclusion that the banking system within GCC countries comprises two different operating banking systems, Islamic and conventional. The overall results show that conventional banks perform well during a political crisis, whereas Islamic banks performed better during the financial crisis. According to Anouze (2015. p. 111), "large and small size GCC commercial banks are more efficient than medium-sized banks".

The studies by Garefalakis et al. are representative of approach in search for the effect of core characteristics of corporate governance on banks' performance during the financial crisis. The results of their research of 86 worldwide banks suggest that boards' independence strongly supports banks' efficiency and operations, as well as external audit contributes positively to banks' efficiency during the crisis period. According to authors (Garefalakis et al., 2017, p. 69), "smaller boards are more efficient and tend to become a win-win strategy for banks' management during the years of economic crisis".

Further improvements in the stability of banking system, for instance, bank credit risk estimate and improving the decision making process of Jordanian banks, are discussed by Al-Shawabkeh and Kanungo (2017). For example, the similar issue is the focus of the international research by Migiro (2017), who explores the issues of optimizing bank's credit portfolio and credit rating as ways of improving the bank performance and finansial stabilization of bank system.

Kodasheva et al. (2017) studied the influence of external and internal factors that impede the development of banking. In particular, the analysis of the banking sector in Kazakhstan showed that the banking sector of Kazakhstan is concentrated in five strategic banks, including subsidiaries of the Russian "Sberbank", which accounts for 50\% of shares in the financial market. The short-term and high-risk consumer loans, which can lead to high credit risks, in case of deterioration of economic situation and high bank dependence on state money are main problems of the banking sector of Kazakhstan.

Authors admit that improving banking sector activities can become a painful process for many participants, because this will require the "reset" of the financial sector in Kazakhstan and additional investment from shareholders or consolidation with other players. According to authors (Kodasheva et al., 2017, p. 259), banking system of Kazakhstan is "“self-organizing", since a change in the economic environment and the political situation will inevitably lead to "automatic" change in the bank's policy".

Ukrainian scientists have made a great scientific contribution into the research of stability of domestic and global banking system. For example, Stukalo et al. (2015) explored the problems of overall efficiency of the major banks in the global financial instability. In particular, authors analyzed main tendencies of functioning world economy in the conditions of global financial crisis in 2008-2010. This gave the possibility to find the tendencies of bank development taking into account global financial instability influence and discribe negative and positive consequences of influence of global financial crisis. According to authors (Stukalo et al., 2015, p. 60), "Globalization significantly affects the level of financial systems stability in developing countries. The negative effects of globalization are manifested in the emergence of global financial crises and bank crises in particular".

For example, Kuznetsova concluded that further consolidation of bank capital in Ukraine is possible with the active participation of the goverment. So, NBU will initiate the conclusion of mergers and acquisitions, in particular by raising the minimum regulatory capital of the bank. According to Kuznetsova $(2014$, p. 8), "In the banks of Ukraine until 2018, it is planned to complete the introduction of Basel III. Such actions will undoubtedly lead to a reduction in the number of banks". In addition, in 
2020, the banking system of Ukraine plans to implement revolutionary structural changes, which will also deal with issues of consolidated processes involving banks (Kuznetsova, 2014).

Dmitrishin and Blahun allocated three basic strategies for the banking sector management, based on the developed cognitive model, the current and forecast changes of internal and external factors, which are determined in accordance with the stated goals of the Ukrainian banking system development. Authors (Dmitrishin \& Blahun, 2014, p. 244), found the following: "The configuration of the banking system is considered as optimal in terms of the development of competition between banks and from the standpoint of ensuring resilience to influences".

Chmutova (2015) examined actual problems of the commercial bank financial priorities at the life cycle stages. She holds that a necessary condition for restoring the Ukrainian banking system is to develop an effective strategy based on the ensuring bank's financial soundness. According to Chmutova (2015, p. 27), "The level of taxonometric indices of the components of the bank's financial soundness related to their life cycle stages. It established financial priorities at each stage of the bank's life cycle".

Thus, the literature review shows the relevance of the chosen topic and a certain scientific uncertainty in the issues of Ukraine's integration into the European banking system under financial instability.

The objective of this article is to analyze the degree of compliance with the Basel III regulations in Ukraine and study the relationship between the stabilization process of the Ukranian banking sector and the program for the implementation of Basel III banking regulatory recommendations.

\section{DATA AND METHODOLOGY}

The global financial crisis of the banking system of 2007-2009 revealed some shortcomings in regulatory requirements for liquidity of banks in America and the European Union and led to the introduction in December 2010 by the Basel Committee on Banking Supervision of updated guidance in the field of banking regulation
Basel III, the final transition to which is scheduled for 2012-2019 (Basel Committee on Banking Supervision, 2017). The main stages of the Basel III Accord implementation by the Basel Committee on Banking Supervision are given in Table 1.

The development of directives and recommendations is carried out in collaboration with the central banks of participating countries and regulatory authorities around the world, and, therefore, they are used not only in the member states of the Basel Committee, but also in other countries. For example, the work on the implementation of Basel II recommendations was conducted in more than 100 countries of the world. In the European Union the recommendations of the Basel Committee are used for the mutual integration of banking systems of the EU member states, with Ukraine also joining this process. The main stages of implementation of Basel III requirements for capital in Ukraine are given in Table 2.

The implementation of Basel III recommendations by the National Bank of Ukraine was started only in 2015, and accordingly, the completion of this process in Ukraine is planned before 2020 , i. e., a year later than it will take place in the Basel Committee member states.

The development of all regulatory and legal acts in relation to Basel III Accord should be completed in the current year. Thus, to test and introduce new capital requirements the next three years are assigned which will lead to the activation of capital buffers and the introduction of new requirements for leverage indicators in 2020.

Adoption of regulations on capital buffers in accordance with Basel III in 2015 was reflected in the Resolution of the Board of the National Bank of Ukraine dated October 20, 2015, No 715 "On Amendments to the Regulation on the Procedure for the Establishment and Use of Reserves by Ukrainian Banks for Reimbursement of Possible Losses through Active Banking Operations" and the Resolution of the Board of the National Bank of Ukraine dated November 26, 2015, No 830 "On Amendments to the Regulation on the Procedure for the Formation and Use by Ukrainian banks of Reserves to Cover Possible Losses through Active Banking Operations". 
Table 1. The main stages of Basel III implementation (2013-2019)

\begin{tabular}{|c|c|c|c|c|c|c|c|c|}
\hline \multicolumn{2}{|r|}{ Stages } & \multirow[t]{2}{*}{2013} & 2014 & 2015 & 2016 & 2017 & 2018 & 2019 \\
\hline \multirow{9}{*}{ Capital } & \multirow{2}{*}{$\begin{array}{l}\text { Leverage ratio } \\
\text { Common equity capital ratio }\end{array}$} & & \multicolumn{4}{|c|}{$\begin{array}{c}\text { Parallel implementation: January 1, } 2013- \\
\text { January } 1,2017 \text {. The dissemination will start } \\
\text { on January 1, } 2015\end{array}$} & $\begin{array}{l}\text { Migration to } \\
\text { pillar } 1\end{array}$ & \multirow[b]{2}{*}{$4.5 \%$} \\
\hline & & $3.5 \%$ & $4.0 \%$ & $4.5 \%$ & $4.5 \%$ & $4.5 \%$ & $4.5 \%$ & \\
\hline & Capital buffer & - & - & - & $0.625 \%$ & $1.25 \%$ & $1.875 \%$ & $2.5 \%$ \\
\hline & $\begin{array}{l}\text { Common equity ratio + capital } \\
\text { buffer }\end{array}$ & $3.5 \%$ & $4.0 \%$ & $4.5 \%$ & $5.125 \%$ & $5.75 \%$ & $6.375 \%$ & $7.0 \%$ \\
\hline & $\begin{array}{l}\text { Percentage of deductions } \\
\text { applicable to common equity } \\
\text { (including tax assets, holdings } \\
\text { in financial institutions, rights } \\
\text { to mortgage debt service) }\end{array}$ & - & $20 \%$ & $40 \%$ & $60 \%$ & $80 \%$ & $100 \%$ & $100 \%$ \\
\hline & Tier 1 ratio & $4.5 \%$ & $5.5 \%$ & \multicolumn{4}{|c|}{$6.0 \%$} & $6.0 \%$ \\
\hline & Total capital ratio & - & \multicolumn{5}{|c|}{$8.0 \%$} & $8.0 \%$ \\
\hline & $\begin{array}{l}\text { Total capital ratio + capital } \\
\text { buffer }\end{array}$ & - & $8.0 \%$ & $8.0 \%$ & $8.625 \%$ & $9.25 \%$ & $9.875 \%$ & $10.5 \%$ \\
\hline & $\begin{array}{l}\text { Capital elements not suitable } \\
\text { for tier } 1 \text { and tier } 2\end{array}$ & - & \multicolumn{6}{|c|}{ To be gradually withdrawn within 10 years since 2013} \\
\hline \multirow[b]{2}{*}{ Liquidity } & Liquidity coverage ratio & - & - & $60 \%$ & $70 \%$ & $80 \%$ & $90 \%$ & $100 \%$ \\
\hline & Net stable funding ratio & - & - & - & - & - & $\begin{array}{l}\text { Minimum } \\
\text { standard is } \\
\text { implemented }\end{array}$ & - \\
\hline
\end{tabular}

Table 2. The main stages of implementation of new requirements for capital in Ukraine (2015-2020)

\begin{tabular}{|c|c|c|c|c|c|c|c|c|}
\hline No. & Indicators & Measures & 2015 & 2016 & 2017 & 2018 & 2019 & 2020 \\
\hline \multirow{2}{*}{1} & \multirow{2}{*}{ Capital buffer } & $\begin{array}{l}\text { Adoption of regulatory } \\
\text { and legal acts }\end{array}$ & $x$ & - & - & - & - & - \\
\hline & & Buffer activation & - & - & - & - & - & $x$ \\
\hline \multirow{3}{*}{2} & \multirow{3}{*}{ New structure of capital } & $\begin{array}{l}\text { Development of regulatory } \\
\text { and legal acts }\end{array}$ & - & $x$ & $x$ & - & - & - \\
\hline & & Test calculations & - & - & $x$ & $x$ & - & - \\
\hline & & $\begin{array}{l}\text { Introduction of new } \\
\text { requirements }\end{array}$ & - & - & - & - & $x$ & - \\
\hline \multirow{3}{*}{3} & \multirow{3}{*}{$\begin{array}{l}\text { Requirements for capital to cover } \\
\text { operational and market risks }\end{array}$} & $\begin{array}{l}\text { Development of regulatory } \\
\text { and legal acts }\end{array}$ & - & - & $x$ & $x$ & - & - \\
\hline & & Test calculations & - & - & - & $x$ & $x$ & - \\
\hline & & $\begin{array}{l}\text { Introduction of new } \\
\text { requirements }\end{array}$ & - & - & - & - & $x$ & - \\
\hline \multirow{3}{*}{4} & \multirow{3}{*}{ Indicator of leverage } & $\begin{array}{l}\text { Development of regulatory } \\
\text { and legal acts }\end{array}$ & - & - & $x$ & $x$ & - & - \\
\hline & & Test calculations & - & - & - & $x$ & $x$ & - \\
\hline & & $\begin{array}{l}\text { Introduction of new } \\
\text { requirements }\end{array}$ & - & - & - & - & - & $x$ \\
\hline
\end{tabular}

\section{RESULTS AND DISCUSSION}

In its turn, the requirements for the implementation of the NBU regulations and stress testing have revealed the failure of many banks in Ukraine to comply with the provisions for reserving funds for possible losses through active banking operations, as evidenced by statistical data. For example, " 33 banks went bankrupt in 2014, the same number - in 2015, 21 - in 2016" (National Bank of Ukraine, 2016), and only two - PSC "Platinum Bank" and PJSC "Bank Boguslav" (National Bank of Ukraine, 2017) - in 2017.

It should be added that the decision of the NBU on withdrawal of the banking license and liquidation of JSC "Bank CHBDR", PJSC "MORSKOY" and PJSC "EASTERN INDUSTRIAL COMMERCIAL BANK" in 2015 was adopted without the preliminary 


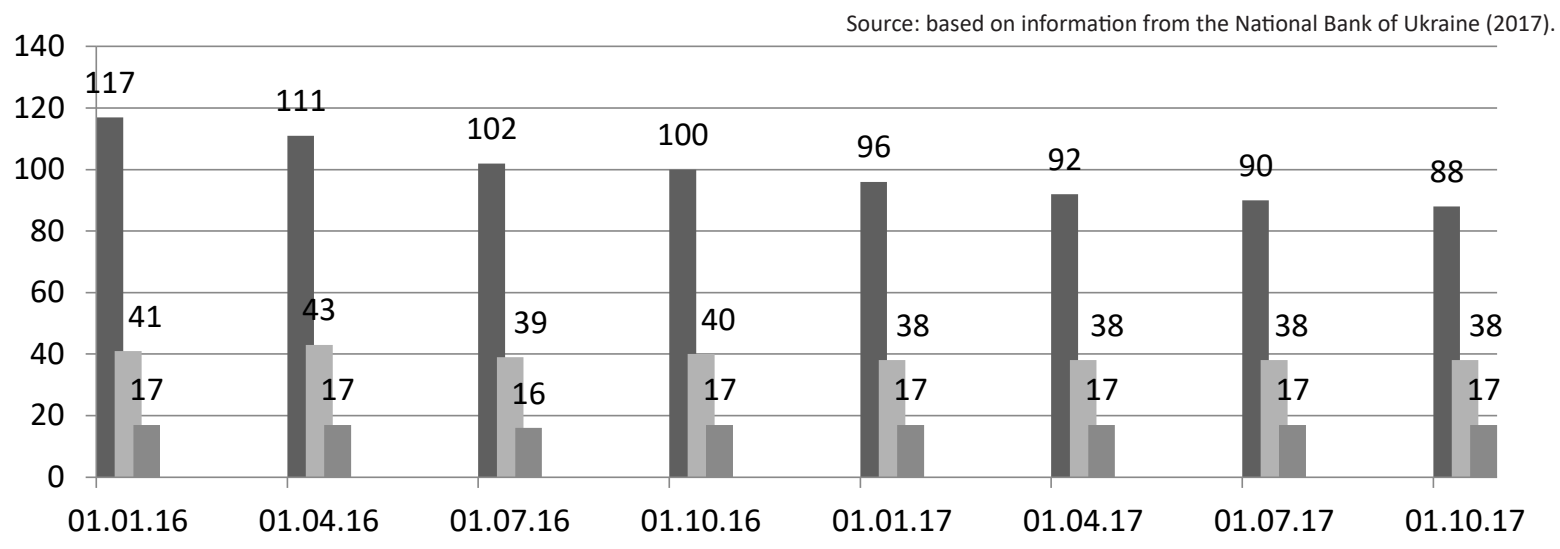

number of banks with a license of the NBU for banking operations, pcs

Number of banks with foreign capital, pcs

Number of banks with $100 \%$ foreign capital, pcs

Figure 1. Dynamics of changes in the number of banks in Ukraine (2016-2017), pcs

introduction of the interim administration. In this case, the reason for such a decision was the impossibility for the NBU to exercise due supervision and control as a result of hostilities in the East of Ukraine and the illegal annexation of the Autonomous Republic of Crimea.

However, the Resolution of the Board of the National Bank of Ukraine dated June 30, 2016, No 351 "On Approval of the Regulation on Determining the Size of Credit Risk by Banks of Ukraine for Active Banking Transactions" became the main regulatory and legal act of the banking system of Ukraine, which abolished the eight previous resolutions of the NBU Board and provided the banking system of the country with clear principles and standards for assessing credit risks and borrowers.

The principles laid down in Resolution No 351 gave a clear understanding of the recognition of credit risk based on the actual solvency of the borrowers and their ability to comply with the terms of the agreement, transparency of banking activities, not only for the NBU, but also for the banks themselves. Thus, since June 2016, the Board of the National Bank of Ukraine decided to consent to the self-liquidation of PJSC "FINANCE BANK", PJSC "Investment-Trust Bank" and JSC FINEXBANK. According to official reports, such decisions were dictated by the desire of these banks' owners to reorient them to other types of their core business (National Bank of Ukraine, 2016).
Since the beginning of 2016, the number of functioning banking institutions has decreased by 21 . Reasons for withdrawal of the banking license and the liquidation of these banks were different. For example, the NBU decided to revoke a banking license and liquidate several banking institutions as a result of violations of banking legislation in the field of financial monitoring. Among them were banks, such as: PJSC "Bank VELES", PJSC "CB PREMIUM", PJSC CB "Soyuz" and PJSC "KSG BANK”.

Also in 2016, the NBU withdrew PJSC "BANK UNISON", JSC CB "TK CREDIT" and PSC "SMARTBANK" from the market "due to the discrepancy of their ownership structure with the requirements for their transparency".

In addition to violating the legislation on preventing and counteracting the legalization (laundering) of proceeds from crime, one of the instruments for recognition of the banks' insolvency and the withdrawal of their banking licenses by the NBU was the inadequate level of their capitalization and the inability of owners (shareholders) to provide the bank with an appropriate level of financial support.

Thus, as of October 1, 2017, only 88 banking institutions have had the licenses of the National Bank of Ukraine including 38 banks with foreign capital. Detailed information on the dynamics of changes in the number of banks in Ukraine is shown in Figure 1. 


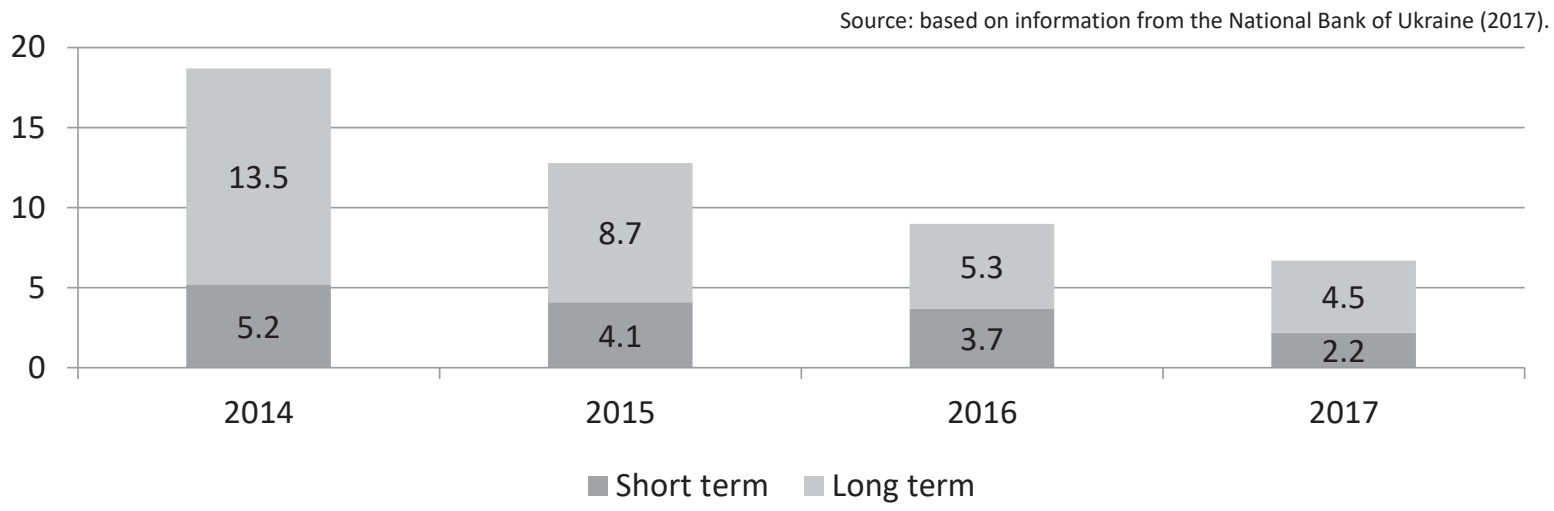

Figure 2. Gross external debt of banks, USD bln

In total, for the period of the year bank licenses were withdrawn by the NBU from 21 banks, including tree banks with a share of foreign capital. The relative stability in the number of banks with foreign capital in the period from 2016 to 2017 and the constant number of banks with $100 \%$ foreign capital indicate that the management of foreign banks have already used the method for calculating the credit risk of borrowers in accordance with Basel III or other similar requirements, based on the assessment of the actual solvency of borrowers and their ability to comply with the terms of the contract.

Implementation of Basel III recommendations by regulating the size of credit risk through active banking operations in accordance with the Resolution of the Board of the National Bank of Ukraine No 351 contributed to reducing the external debt of banks as well as the number of lossmaking banks in Ukraine.
In recent years, the gross external debt of banks in foreign currency has a tendency to decrease annually. The dynamics of gross external debt of banks in foreign currency in 2014-2017 is shown in Figure 2.

The reduction of the gross external debt of banks has a correlation with the total number of unprofitable banks in the period from 2014 to 2017. The dynamics of the number of unprofitable banks is shown in Figure 3.

So, since 2015, when the National Bank of Ukraine began implementing the Basel III recommendations, the number of unprofitable banks, banks with negative operating income and negative net interest income is constantly decreasing.

According to the results of 2016, the list of three most harmful Ukrainian banks included PJSC "UKRSOCBANK", which was in process of merging

Source: based on information from the National Bank of Ukraine (2017).

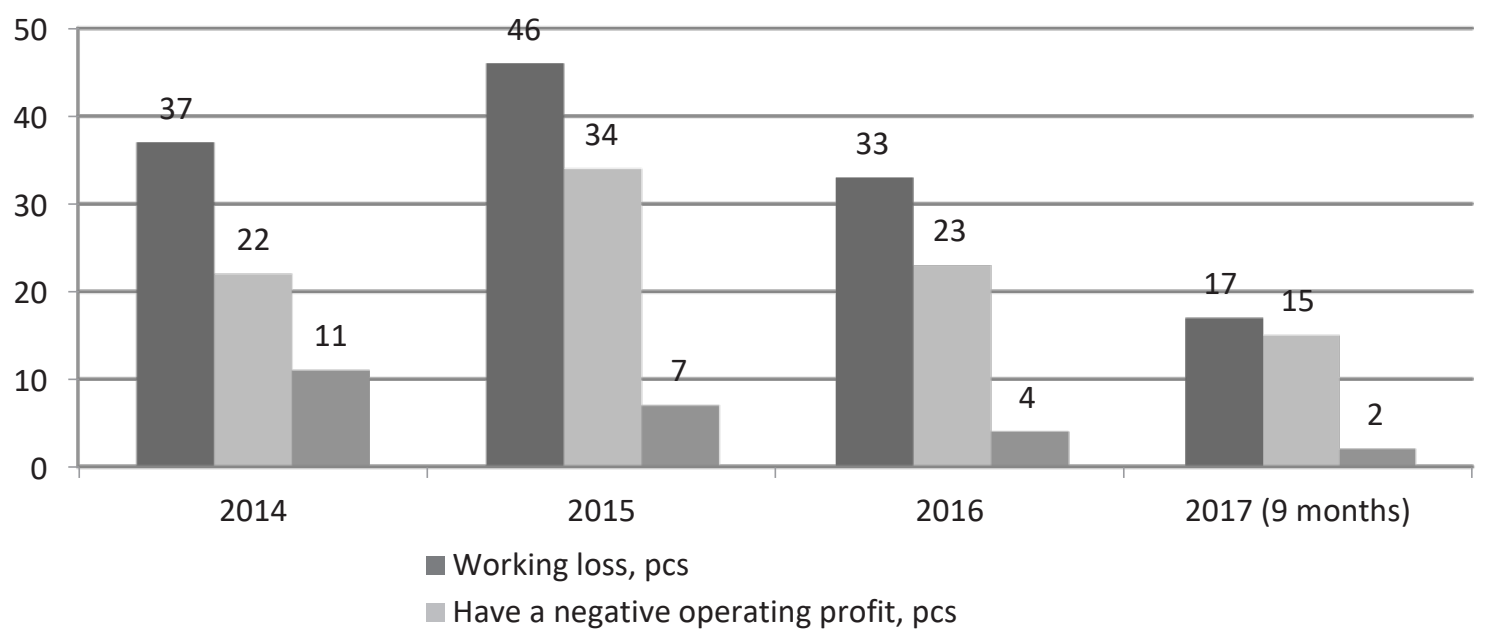

Figure 3. The number of unprofitable banks, pcs 


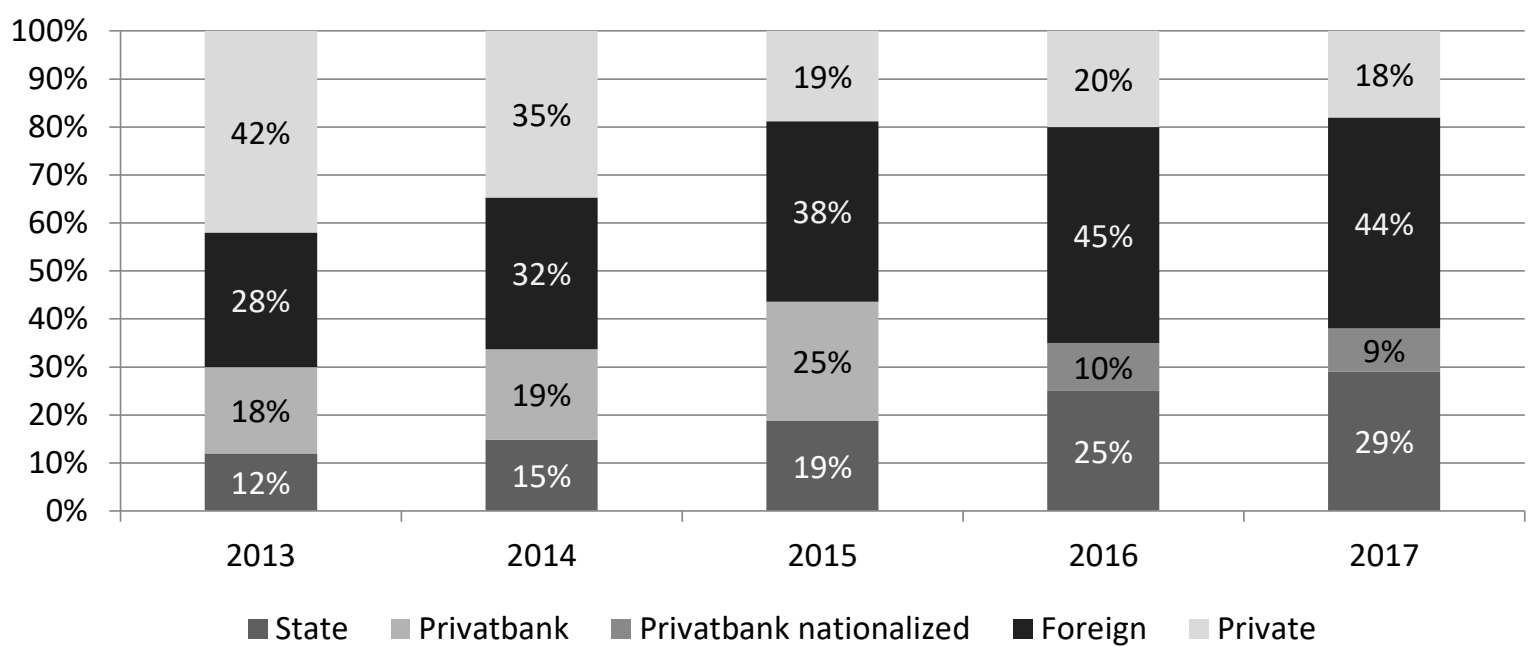

Figure 4. Net loans by groups of Ukrainian banks, \%

with the group of PJSC "Alfa-Bank", PJSC "VTB BANK" as well as PJSC CB "PRIVATBANK", which was nationalized at the end of the year. At the same time, among the most lucrative banks for the same period were only foreign financial institutions - JSC Raiffeisen Bank Aval, PJSC "CITYBANK" and JSC "OTP BANK". So the top-3 most profitable banks by the end of 2016 accounted for $57.5 \%$ of the total profits received last year by the banking system of Ukraine (National Bank of Ukraine, 2016).

Thus, it confirms once again that the application of Basel III recommendations by the banking system of Ukraine, which have been successfully applied by foreign banks in their activities, will allow not only to reduce the number of unprofitable banks but also to make them profitable. But it should be stressed that not all Ukrainian banks will be able to pass testing and adaptation.

It should also be noted that, in the current situation, foreign banks with their effective system of managing credit risks consistently occupy the largest share of net loans $-44 \%$, while state banks, even taking into account the nationalization of PJSC CB "PRIVATBANK", cover only $38 \%$ of the Ukrainian credit market. Net loans by groups of Ukrainian banks are shown in Figure 4.

The analysis of deposits of the population by groups of banks has also shown relative stability of the share of foreign banks. Deposits of the population by groups of Ukrainian banks are shown in Figure 5.
In the period from 2013 to 2017, the private banks lost the largest share of the market, which was taken over by state-owned banks, including the nationalized Privatbank. Foreign banks have not been interested in attracting deposits from the population, as evidenced by low interest rates on deposits in national and foreign currencies.

Consequently, since 2013, the banking sector of Ukraine has undergone some changes: as a result of the transformation of the privately-owned Privatbank into the state-owned bank, the bankruptcy of several dozens of private banks, the structure of the banking system of the state has changed significantly, while the system as a whole has coped well with this transformation in terms of improving financial stability.

The empirical data show that foreign banks have been more financially stable than private and state banks. Moreover, their stability has been observed throughout the analyzed period.

It should be noted that the desire of foreign banks to lend to the Ukrainian economy and the Ukrainian population significantly affects the liquidity of the entire banking system of the country. The analysis of banking programs for auto lending to individuals in foreign banks showed that the fulfillment of their requirements for the formation and use of reserves for the reimbursement of possible losses through active banking operations is carried out at the expense of initial contributions 
Source: based on information from the National Bank of Ukraine (2017).

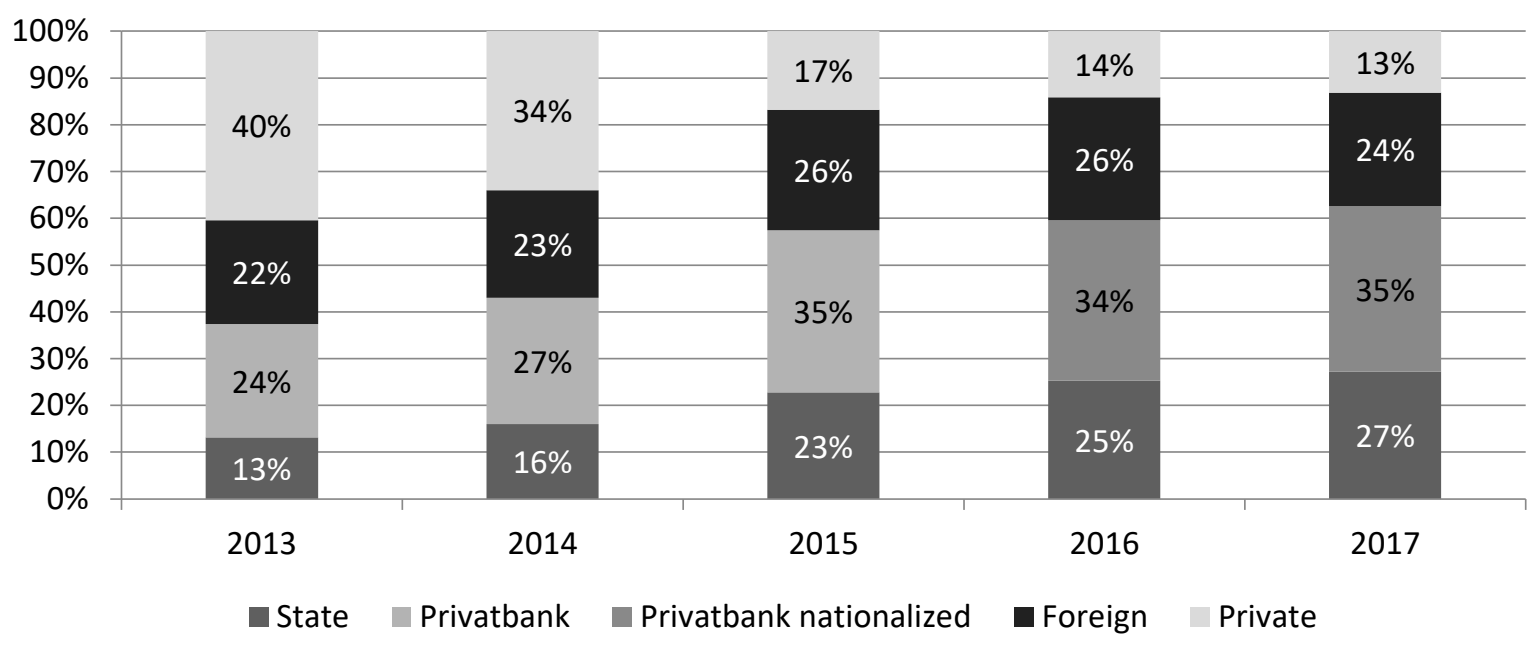

Figure 5. Net deposits of the population by groups of banks, $\%$

Table 3. Loans for a new car of foreign production (dated November 2017)

Source: formed by authors (Ukrainian Bank Portal, 2017).

\begin{tabular}{|c|c|c|c|c|c|c|c|c|c|c|}
\hline \multirow[t]{2}{*}{$\begin{array}{c}\text { Type } \\
\text { of bank }\end{array}$} & \multirow[t]{2}{*}{ Name } & \multirow{2}{*}{$\begin{array}{c}\text { Name } \\
\text { of the auto } \\
\text { credit program }\end{array}$} & \multicolumn{2}{|c|}{$\begin{array}{l}\text { Sum of credit, } \\
\text { UAH ths }\end{array}$} & \multicolumn{2}{|c|}{$\begin{array}{c}\text { Initial } \\
\text { payment from } \\
\text { sum of credit, } \\
\%\end{array}$} & \multicolumn{2}{|c|}{$\begin{array}{c}\text { Credit period, } \\
\text { months }\end{array}$} & \multicolumn{2}{|c|}{ Loan rate, $\%$} \\
\hline & & & $\min$ & $\max$ & $\min$ & $\max$ & $\min$ & $\max$ & $\min$ & $\max$ \\
\hline \multirow{4}{*}{ Foreign } & UkrSibBank & New auto & 150 & 800 & 15 & 40 & 12 & 84 & 11 & 17 \\
\hline & Credobank & Credoauto & 150 & 1000 & 10 & 50 & 12 & 84 & 14.49 & 20.99 \\
\hline & $\begin{array}{l}\text { Credit Agricole } \\
\text { Bank }\end{array}$ & $\begin{array}{l}\text { "Partnership" } \\
\text { program }\end{array}$ & 200 & 1000 & 10 & 60 & 12 & 84 & 0.01 & 15.99 \\
\hline & OTP Bank & Optimal choice & 200 & 1000 & 20 & 60 & 12 & 72 & 0.01 & 17.49 \\
\hline \multirow{4}{*}{ State } & Ukrgazbank & $\begin{array}{l}\text { "Standard" auto } \\
\text { credit }\end{array}$ & 10 & 700 & 10 & 50 & 12 & 84 & 6.49 & 14.99 \\
\hline & Privatbank & $\begin{array}{l}\text { Auto credit from } \\
\text { Privatbank }\end{array}$ & 2 & 800 & 10 & 99.9 & 12 & 60 & - & 28 \\
\hline & Oschadbank & $\begin{array}{l}\text { Credit program } \\
\text { No.1 }\end{array}$ & 0 & 3000 & 10 & 99.9 & 12 & 84 & 0.01 & 16.99 \\
\hline & Ukreximbank & Means of transport & 50 & 1000 & 15 & & 12 & 60 & 17.5 & - \\
\hline \multirow{4}{*}{ Private } & TAScombank & $\begin{array}{l}\text { "Go for your } \\
\text { dream" }\end{array}$ & 150 & 1000 & 20 & 60 & 12 & 84 & 0.01 & 17.6 \\
\hline & Idea bank & $\begin{array}{l}\text { Cash loan to buy } \\
\text { a car }\end{array}$ & 1 & 200 & 0 & 99.9 & 6 & 60 & 15 & 21.99 \\
\hline & Globus Bank & Auto in credit & 10 & 2000 & 10 & 50 & 12 & 84 & 14 & 19 \\
\hline & Pivdennyi & "Your new auto" & 1 & $\begin{array}{l}80 \% \text { of } \\
\text { price }\end{array}$ & 20 & 50 & 12 & 84 & 16.9 & 19.9 \\
\hline
\end{tabular}


of borrowers. The main banks - players in the Ukrainian car loan market are grouped into Table 3.

Comparisons of the conditions of auto lending by groups of banks have shown that foreign banks within the group have roughly the same amount terms of loans and the percentage of ini- tial contribution from the sum of a car loan. In addition, the lowest loan rates are offered by $50 \%$ of investigated foreign banks, while public and private banks have a $25 \%$ share in their group. In addition, it is difficult to identify a certain grouping in the terms of auto lending by state and private banks because they radically differ from each other.

\section{CONCLUSION}

Consequently, the introduction by the banking system of Ukraine of anti-crisis measures in response to shortcomings in financial regulation along with the implementation of Basel III methodological recommendations in the field of banking regulation helped not only to identify and remove a "malignant tumor" on the "body" of the banking system, but also to enable it to survive and start a new phase in the EU banking environment.

\section{Prospects for further research}

The banking system is a pivotal element of the economy of any country. Today, many scholars and experts in banking regulation consider Basel II and Basel III recommendations of the Basel Committee on Banking Supervision as an effective tool for integrating the banking systems of the EU member states. At the same time, the implementation of the Basel Committee on Banking Supervision recommendations in the banking system of Ukraine revealed certain individual features in the process of implementing Basel common standards.

\section{Cleaning the banking system as a prerequisite for change}

In this case, it is about the firm decision of the regulator to withdraw from the financial market of Ukraine profitable banks with an "opaque ownership structure", banks - violators of legislation in the field of financial monitoring and banks outside its influence located on the territory of combat operations in the East of Ukraine and the illegally annexed Autonomous Republic of Crimea. Cleaning the banking system is a key as it will strengthen Ukrainian banks and, therefore, financial stability.

\section{Optimization of the banking system as an effective tool for anti-crisis management}

In the context of the falling national currency and military operations on the territory of the country, some Ukrainian banks conducted an ineffective policy of creating reserves to compensate for potential losses through active banking operations. All this contributed to the withdrawal of insolvent banking institutions from the banking market due to their inadequate capitalization and the inability of owners (shareholders) to provide the banks with an adequate level of financial support. The same applied to the banks that were incapable of complying with reserve provisions for potential losses through active banking operations, and the banks that at will of their owners decided to reorient themselves to other types of financial activities.

\section{Banks with foreign capital are the most stable in the banking system of Ukraine}

Their largest share in the market of loans is $44 \%$, a significant share in the deposit market - $35 \%$, and the number of banks is stable - only two of them with foreign capital were not licensed by the NBU in 2016, while banks with $100 \%$ foreign capital have all remained in the market. 
Thus, the implementation of Basel III recommendations in the banking system of Ukraine has broad prospects and needs for constant attention from the banking sector including all state, private and foreign banks in order to consolidate the stability of the financial system of the country as a whole.

\section{REFERENCES}

1. Adesina, K. S., \& Mwamba, J. M. (2015). Effects of Basel III higher capital requirements via bank lending rates in Africa: a preliminary assessment. Banks and Bank Systems, 10(4), 51-61.

2. Al-Shawabkeh, A., \& Kanungo, R. (2017). Credit risk estimate using internal explicit knowledge. Investment Management and Financial Innovations, 14(1), 5566. http://dx.doi.org/10.21511/ imfi.14(1).2017.06

3. Angelini, P., Clerc, L., Cúrdia, V., Gambacorta, L., Gerali, A., Locarno, A., Motto, R., Roeger, W., Heuvel, S., Van den, \& Vlček, J. (2015). Basel III: Long-term Impact of Capital and Liquidity Requirements. The Manchester School, 83(2), 217-251. http:// dx.doi.org/10.1111/manc.12056

4. Anouze, A. L. (2015). Efficiency of performance of banks in the Gulf region before, during and after crises (Financial and Political). Developing Inclusive and Sustainable Economic and Financial Systems, 3(7), 111125. Retrieved from http://www. wijdantariq.com/wp-content/ uploads/2016/05/Islamic-FinanceBook_Volume_3.pdf $\#$ page $=12$

5. Basel Committee on Banking Supervision (2013). Basel III: The liquidity coverage ratio and liquidity risk monitoring tools. Bank for International Settlements (BIS) Publications. Retrieved from http:// www.bis.org/publ/bcbs238.htm.

6. Basel Committee on Banking Supervision (2017). Basel III Monitoring Report. Retrieved from https://www.bis.org/bcbs/ $\mathrm{publ} / \mathrm{d} 416 . \mathrm{htm}$

7. Boccuzzi, G. (2016). The New European Framework for Banking Crisis Management. Will it be enough? Open Review of Management. Banking and Finance. Retrieved from https:// openreviewmbf.org/2016/03/12/ the-new-european-frameworkfor-banking-crisis-managementwill-it-be-enough/

8. Chmutova, I. (2015). Commercial bank financial priorities on the life circle stage. The Advanced Science Journal, 5, 27-34. http://dx.doi. org/10.15550/ASJ.2015.05.027

9. Cohen, B. H., \& Scatigna, M. (2016). Banks and capital requirements: Channels of adjustment. Journal of Banking \& Finance, 69(1), 56-69.

10. Dmitrishin, L. I., \& Blahun, I. I. (2014). Development of a Mechanism of the Formation of Strategies for Management of the Banking System in Ukraine. Business-inform. Finance, money circulation and credit, 11(442), 238-245, [in Ukrainian].

11. Garefalakis, A., Augustinos, D., \& Lemonakis, C. (2017). The effect of corporate Governance Information (cGI) on banks' reporting performance. Investment Management and Financial Innovations, 14(2), 6370. http://dx.doi.org/10.21511/ imfi.14(2).2017.06

12. Kinyariro, D. K., Meeme, M. M., Maina, J. N., \& Muriithi, M. J (2016). Implications of Basel III accord adherence on financial distress status of commercial banks in Kenya. International Journal of Economics. Commerce and Management, 4(7), 691-705.

13. Kodasheva, G., Parusimova, N., Rispekova, M. \& Uchkampirova, A. (2017). Actual problems of development of the banking sector in the economy of Kazakhstan. Banks and Bank System, 12(3), 257-268. http://dx.doi. org/10.21511/bbs.12(3-1).2017.10

14. König, E. (2017). Implementing an efficient resolution framework in the Banking Union: lessons from the crisis and challenges ahead,
71-76. Retrieved from https://publications.banque-france.fr/sites/ default/files/medias/documents/ fsr21_web.pdf

15. Kuznetsova, A. (2014). The current state and prospects of consolidation of banks in Ukraine in the post-crisis period. Bulletin of the Ukrainian Academy of Banking, 1(36), 6-9, [in Ukrainian].

16. Lucchini, S., Moscianese, J., de Angelis, I., \& Di Benedetto, F. (2017). State Aid and the Banking System in the Financial Crisis: From Bail-out to Bail-in. European Competition Law \& Practice, 8(2), 88-98.

17. Migiro, S. (2017). Post National Credit Act reckless lending in the South African banking industry. Public and Municipal Finance, 6(2), 27-34. http://dx.doi.org/10.21511/ pmf.06(2).2017.03

18. National Bank of Ukraine (2016). The National Bank of Ukraine changed the approach to credit risk assessment by banks. Retrieved from https://bank.gov.ua/ control/en/publish/printable_ar ticle;jsessionid=7C60BD4F398 A5D199796155DE4525CED?a rt_id $=32898626 \&$ showTitle $=$ true

19. National Bank of Ukraine (2017). Financial indicators of Ukraine's financial reporting. Retrieved from https://bank.gov.ua/ control/uk/publish/article?art_ id=34661442\&cat_id=34798593

20. National rating agency "Rurik" (2016). Analytical review of the banking system of Ukraine based on results of 2016. Retrieved from http://rurik.com.ua/documents/research/bank_system_4_ kv_2016.pdf

21. Stukalo, N. V., Lytvyn, M. V., \& Polishko, H. H. (2015). Теоретико-методологічні основи глобальної финансової 
кризи [Teoretyko-metodolohichni osnovy hlobalnoi finansovoi

kryzy]. Ekonomichnyi prostir, 101, 51-61, [in Ukrainian].

22. Š́torová, B. \& Teplý, P. T. (2013). The Impact of Basel III on Lending Rates of EU Banks. Finance a úvČrCzech Journal of Economics and Finance, 63(3), 226-243.

23. Ukranian Bank Portal (2017). Credits for cars in banks of Ukraine. Calculate the loan. Retrieved from http://banker.ua/ credit/car/
24. Weigand, R. A. (2016). The performance and risk of banks in the U.S. Europe and Japan post-financial crisis. Investment Management and Financial Innovations, 13(4), 75-93. http://dx.doi.org/10.21511/ imfi.13(4).2016.07

25. Закон України Про спрощення процедур реорганізації та капіталізації банків № 1985 VIII від 23.03.2017 року [Zakon Ukrainy "Pro sproshchennia procedur reorghanizatsii ta kapitalizatsii bankiv" No 1985 - VIII vid 23.03.2017 roku]. Retrieved from http://zakon3.rada.gov.ua/ laws/ show/1985-19

26. Національний банк України (2017). Про спрощення процедури капіталізації та реорганізації банків: проект Закону України [Natsionalnyi Bank Ukrainy (2017). Pro sproshchennia protsedur kapitalizatsii ta reorhanizatsii bankiv: proekt Zakonu Ukrainy]. Retrieved from http:// w1.c1.rada.gov.ua/pls/zweb2/ webproc4_1?pf3511=61037 